\title{
STRATEGI MINIMALISASI NILAI PROVISI MATERIAL TERHADAP HEALTHY INVENTORY
}

\author{
Merdieco Rivandi \\ Program Studi Teknik Industri / Politeknik Meta Industri Cikarang / \\ merdieco@politeknikmeta.ac.id
}

\begin{abstract}
Healthy inventory is an indicator of a company's financial well-being. An unbalanced inventory will cause company chaos in the form of too much inventory, or not enough inventory, both of which can destroy the revenue of a company. There are many great challenges to be faced in controlling the proper inventory. When a company has an inventory level that is too large, it will result in the emergence of large capital embedded in inventory, increased storage costs, and the risk of damage or loss of goods. However, if the company has too little inventory, it will result in the risk of a shortage of inventory (stockout) because not all materials/goods can be imported suddenly and as much as needed considering the capacity and waiting time at the supplier, thus allowing for additional costs when bring in the goods by making special deliveries so that the goods can arrive faster, so that this shortage of inventory can cause the production process to stop, sales delays, and even the loss of customers. The risk of excessive and piled up inventory will potentially expire, be damaged, or lost and all of these risks will lead to potential additional costs that are included in the cost of material provisions. All cost estimates related to existing inventory levels due to miscalculations will be provision costs that must be borne by the company. The cost of this provision will cause a loss and will automatically reduce the profit generated, so many companies will make various strategies to avoid the cost of this provision.
\end{abstract}

Keywords : provision value, material provision, healthy inventory

\begin{abstract}
ABSTRAK
Persediaan yang sehat (healthy inventory) adalah merupakan sebuah indikator dari kesejahteraan finansial perusahaan. Persediaan yang tidak seimbang akan menyebabkan kekacauan perusahaan dalam bentuk terlalu banyak persediaan, atau tidak cukup persediaan, yang keduanya dapat menghancurkan pendapatan dari sebuah perusahaan. Banyak tantangan besar yang harus dihadapi dalam mengendalikan persediaan yang tepat. Saat perusahaan memiliki tingkat persediaan yang terlalu besar maka akan mengakibatkan timbulnya modal yang besar yang tertanam dalam persediaan, meningkatnya biaya penyimpanan, dan risiko kerusakan atau kehilangan barang. Namun, jika perusahaan memiliki tingkat persediaan terlalu sedikit maka akan mengakibatkan risiko terjadinya kekurangan persediaan (stockout) karena tidak semua bahan/barang dapat didatangkan secara mendadak dan sebesar yang dibutuhkan mengingat adanya kapasitas dan waktu tunggu yang ada di pemasok, sehingga memungkinkan adanya biaya tambahan saat mendatangkan barang tersebut dengan melakukan pengiriman khusus agar barang dapat datang lebih cepat, sehingga kekurangan persediaan ini dapat menyebabkan terhentinya proses produksi, tertundanya penjualan, bahkan dapat membuat hilangnya pelanggan. Risiko persediaan yang berlebihan dan menumpuk akan berpotensi kadaluarsa, rusak, atau hilang dan semua risiko ini akan menyebabkan potensi biaya tambahan yang masuk dalam biaya provisi material. Semua perkiraan biaya yang berhubungan dengan tingkat persediaan yang ada akibat kesalahan perhitungan akan menjadi biaya provisi yang harus ditanggung oleh perusahaan. Biaya provisi ini akan menyebabkan kerugian dan secara otomatis akan mengurangi keuntungan yang dihasilkan, sehingga banyak perusahaan akan membuat berbagai macam strategi utnuk menghindari biaya provisi ini.
\end{abstract}

Kata Kunci : nilai provisi, provisi material, persediaan 


\section{PENDAHULUAN}

Setiap perusahaan akan selalu berusaha untuk mengoptimalkan keuntungan karena keuntungan ini akan berdampak pada kelangsungan usahanya. Salah satu strategi yang paling penting dalam meningkatkan pencapaian laba perusahaan adalah dengan mengendalikan persediaan. Persediaan merupakan salah satu aset perusahaan yang dapat berupa persediaan bahan baku atau bahan mentah (raw materials), persediaan barang dalam proses produksi atau dapat dikatakan juga dengan barang setengah jadi (work in process), dan barang jadi yang sudah melewati proses produksi secara keseluruhan dan siap untuk dijual (finished good). Persediaan yang sehat (healthy inventory) adalah merupakan sebuah indikator dari kesejahteraan finansial perusahaan. Persediaan yang tidak seimbang akan menyebabkan kekacauan perusahaan dalam bentuk terlalu banyak persediaan, atau tidak cukup persediaan, yang keduanya dapat menghancurkan pendapatan dari sebuah perusahaan. Pemantauan dengan bantuan perangkat lunak (software) persediaan adalah pendekatan proaktif untuk mengidentifikasi area mana yang diperlukan perbaikan.

Sebelumnya sudah banyak beberapa artikel, tulisan dan jurnal yang membahas tentang manajemen persediaan, bagaimana mengelola persediaan dengan baik, strategi apa yang harus dilakukan dan beberapa pembahasan lainnya. Namun dalam tulisan kali ini, penulis mencoba untuk melihat dan membahas dari sudut pandang biaya yang sedikit detail ketika terlibat dalam mengelola tingkat persediaan dan sedikit banyak juga akan mempangaruhi keuntungan perusahaan.

Pada saat ini, mungkin kita akan bertanya "apa yang dimaksud dengan persediaan yang sehat?" sayangnya jawabannya adalah "itu akan tergantung pada bisnis anda". Berbagai faktor menyebabkan manajemen persediaan yang baik termasuk analisis terus menerus dari suplai dan permintaan (supply and demand) juga persediaan pergantian (inventory turnover). Persediaan mempunyai nilai yang cukup besar dan mempengaruhi biaya operasi sehingga persediaan menjadi salah satu aset yang penting dalam sebuah perusahaan yang harus dikendalikan dan harus menjadi perhatian khusus dari manajemen perusahaan.

dalam Persediaan atau inventory dapat diartikan sebagai semua sumber daya yang terdapat dalam sebuah organisasi yang akan digunakan untuk mengantisipasi dan memenuhi permintaan yang ada. Selain itu, dapat dikatakan juga bahwa persediaan sebagai sumber daya yang menganggur (idle resource) yang ada pada suatu organisasi. Karena pentingnya persediaan ini, beberapa akuntan selalu memasukkan persediaan dalam neraca sebagai salah satu pos aktiva lancar. Persediaan adalah modal perusahaan yang menganggur yang tidak dapat digunakan untuk keperluan yang lain sebelum persediaan tersebut digunakan, di proses produksi dan kemudian dijual ke pelanggan.

Setiap bagian yang ada dalam suatu perusahaan memiliki pandangan berbeda-beda tentang persediaan. Bagian pemasaran selalu menginginkan tingkat persediaan yang relatif banyak agar mereka dapat melayani serta mengantisipasi permintaan pelanggan sebaik mungkin. Untuk menghemat biaya pemesanan dan pengiriman juga mendapatkan potongan harga, bagian pembelian tentunya akan memilih untuk membeli barang dalam jumlah yang besar sehingga harga per unit barang akan menjadi lebih murah. Begitu juga dengan bagian produksi, yang menginginkan tingkat persediaan yang relatif besar agar mereka dapat mencegah terganggunya proses produksi karena kekurangan bahan. Di bagian yang lain, bagian keuangan cenderung akan memilih tingkat persediaan yang serendah mungkin sehingga dapat memperkecil modal yang harus dikeluarkan dalam persediaan dan biaya-biaya lain yang terlibat dalam mengelola persediaan seperti biaya pergudangan atau penyimpanannya.

Hal yang sering terjadi dalam sebuah industri adalah karena adanya kesalahan forecast sehingga inventory selalu menjadi tidak benar. Jika hal tersebut benar-benar terjadi maka kemungkinan 
yang akan terjadi, barang akan menumpuk di gudang dalam jangka waktu yang cukup lama dan berpotensi kadaluarsa, sehingga tentunya kita membutuhkan strategi jitu untuk mengatasi hal tersebut. Risiko persediaan yang menumpuk dan berpotensi kadaluarsa, rusak, atau hilang tersebut akan masuk dalam nilai provisi material yang harus diperhitungkan dan dikelola dengan baik. Pengendalian persediaan harus dilakukan sedemikian baik agar dapat melayani kebutuhan bahan/barang dengan tepat dan dengan minimalisasi biaya yang terjadi.

\section{METODOLOGI}

Karya Ilmiah ini disusun menggunakan metode penelitian kepustakaan. Yaitu metode penelitian yang mencari sumber dari beberapa buku dan artikel yang telah ada dan aplikasi nyata yang ada di industri. Tahapan awal penelitian ini melihat permasalahan yang ada ketika margin review berdasarkan pengalaman penulis saat terlibat dalam manajemen persediaan, dari tahapan awal tersebut diketahui bahwa terdapat penyimpangan margin yang seringkali terjadi, kemudian selanjutnya dilakukan studi literatur dari artikel, paper, jurnal, dan lain sebagainya untuk mencari informasi yang memang berkaitan dengan materi penelitian.

\section{HASIL DAN PEMBAHASAN}

\subsection{Manajemen Persediaan}

Manajemen persediaan adalah penyimpanan barang atau bahan baku yang kemudian nantinya akan digunakan untuk memenuhi permintaan tertentu seperti untuk digunakan dalam proses perakitan dan produksi atau digunakan untuk suku cadang dari suatu mesin atau peralatan. Jenis persediaan ini dapat berupa bahan mentah atau bahan baku, bahan pelengkap atau bahan pembantu, barang yang masih dalam proses, barang yang telah selesai melewati semua proses produksi atau barang jadi, ataupun berupa barang suku cadang. Banyak tantangan besar yang harus dihadapi dalam mengendalikan persediaan yang tepat. Saat perusahaan memiliki tingkat persediaan yang terlalu besar maka akan mengakibatkan timbulnya modal yang besar yang tertanam dalam persediaan, meningkatnya biaya penyimpanan, dan risiko kerusakan atau kehilangan barang. Namun, jika perusahaan memiliki tingkat persediaan terlalu sedikit maka akan mengakibatkan risiko terjadinya kekurangan persediaan (stockout) karena tidak semua bahan/barang dapat didatangkan secara mendadak dan sebesar yang dibutuhkan karena adanya kapasitas dan waktu tunggu (leadtime) di sisi pemasok, sehingga berpotensi adanya biaya tambahan saat mendatangkan barang tersebut dengan pengiriman khusus agar barang dapat datang lebih cepat, sehingga kekurangan persediaan ini dapat menyebabkan terhentinya proses produksi, tertundanya penjualan, bahkan hilangnya pelanggan. Pengendalian persediaan harus dilakukan sedemikian rupa dengan berbagai macam strategi agar dapat memenuhi kebutuhan bahan/barang dengan tepat sesuai permintaan pelanggan tentunya dengan minimalisasi biayabiaya yang terlibat dalam persediaan.

Manajemen persediaan yang baik adalah manajemen persediaan yang secara konsisten dapat menjaga keseimbangan antara investasi persediaan dengan tingkat pelayanan yang baik kepada konsumen. Persediaan yang ada dalam perusahaan manufaktur umumnya meliputi bahan baku atau bahan mentah (Raw Materials), barang-barang yang masih dalam proses produksi (Work In Process), bahan-bahan pembantu atau bahan pelengkap (sub materials), komponen-komponen hasil rakitan dari perusahaan lain maupun perusahaannya sendiri (assembled components/modules) dan juga persediaan barang jadi yang sudah melewati semua proses produksi dan siap untuk dikirimkan atau dijual ke pelanggan (Finished Goods). Namun ada juga beberapa perusahaan atau organisasi yang memasukkan modal, mesin, tenaga kerja, ruangan yang belum ditempati (space), suku cadang dan peralatan lainnya sebagai persediaan untuk memenuhi permintaan pelanggan.

Dapat dikatakan bahwasannya proses produksi merupakan suatu proses yang dinamis karena adanya pergerakan barang saat proses tersebut berlangsung. Untuk itu, agar tidak mengganggu keberlangsungan proses produksi, maka diperlukan suatu cara pengelolaan yang baik terhadap 
barang tersebut. Pengelolaan yang dimaksud disini adalah dengan manajemen persediaan. Berdasarkan jenis barang yang dikelola, manajemen persediaan ini terbagi menjadi 5 jenis persediaan;

1. Barang Mentah atau Bahan Baku.

Dalam hal manajemen persediaan, perusahaan harus mampu memastikan bahwa jumlah dari bahan mentah atau bahan baku yang tersedia mampu mecukupi kebutuhan proses produksi yang sudah direncanakan.

2. Barang Proses atau Barang Setengah Jadi.

Barang ini dapat digunakan untuk didisribusikan ke pabrik atau lokasi yg lain sebagai barang sub assy untuk dilanjutkan menjadi barang jadi. Manajemen persediaan akan menentukan seberapa banyak barang yang diperlukan untuk di distribusi agar bisa memenuhi permintaan.

3. Barang Jadi atau finished goods.

Barang yang masuk dalam kelompok ini adalah barang yang sudah melewati proses produksi secara lengkap dan siap untuk dijual atau dikirimkan ke pelanggan. Nantinya dalam tahapan manajemen persediaan akan diatur jumlah barang jadi yang sudah tersedia untuk didistribusikan kemana, berikut dengan berapa banyak jumlahnya dengan tujuan mendapatkan jumlah produk optimal agar mendapatkan keuntungan yang maksimal.

4. Barang Suplai.

Manajer persediaan harus mampu mengelola barang yang akan menjadi persediaan dengan baik, apakah barang tersebut yang akan digunakan untuk produksi atau tidak.

5. Barang Dagangan.

Barang ini harus jelas akan didistribusikan kemana, kapan waktunya dan berapa banyak jumlahnya.

Biaya-biaya yang terlibat dalam persediaan dapat digolongkan menjadi tiga, yaitu:

- Biaya Pemesanan (ordering cost, procurement costs)

Biaya ini adalah biaya yang harus ditanggung yang berhubungan dengan proses pemesanan bahan/barang, mulai dari penempatan pemesanan (purchase order release) sampai barang yang di pesan tersubut tersedia di gudang. Yang termasuk dalam biaya pemesanan ini meliputi semua biaya administrasi penempatan order, biaya saat pemilihan pemasok, biaya angkut dan bongkar muat barang, hingga biaya penerimaan dan pemeriksaan barang tersebut.

- Biaya Penyimpanan (carrying costs, holding costs)

Biaya ini adalah biaya yang harus dikeluarkan karena diadakannya persediaan barang. Yang termasuk dalam biaya ini antara lain adalah biaya sewa tempat atau sewa gudang, biaya administrasi pergudangan, biaya pelaksana pergudangan, biaya beban listrik, biaya modal yang terdapat dalam persediaan barang, biaya kerusakan, kehilangan atau penyusutan barang selama penyimpanan, biaya asuransi jika memang ada dan diperlukan.

- Biaya Kekurangan Persediaan (shortage costs, stockout costs)

Biaya ini adalah biaya yang timbul akibat tidak tersedianya barang pada saat diperlukan dalam proses produksi. Karena terganggunya proses produksi yang mengakibatkan stop line, maka biaya kehilangan waktu produksi, mesin dan juga waktu kerja karyawan dianggap sebagai biaya hilangnya kesempatan. 
Proses manajemen persediaan yang dilakukan didalam sebuah perusahaan tentunya akan memerlukan biaya, terlebih jika perusahaan tersebut mengelola atau membuat persediaan barang-barang yang memang memerlukan perhatian khusus seperti contohnya adalah makanan yang bisa kadaluarsa atau basi, barang-barang pecah belah, barang-barang yang teknologinya cepat berkembang, dan lain sebagainya. Barang-barang ini akan sanagat memerlukan penanganan yang cepat dan biaya perawatan yang relatif mahal. Dari hal contoh-contoh tersebut, maka tujuan utama dari manajemen persediaan adalah bagaimana dapat memaksimalkan barang persediaan dengan biaya yang minimal mungkin. Ada beberapa tujuan lain yang bermanfaat melalui manajemen persediaan, diantaranya;

- Mempertimbangkan adanya persediaan melalui safety stock

- Membuat peramalan untuk mengantisipasi lonjakan atau penurunan permintaan

- Perubahan permintaan dan penawaran dapat di antisipasi

- Risiko kenaikan harga dapat ditekan atau dikurangi

- Menjaga persediaan bahan yang dihasilkan secara musiman

- Risiko keterlambatan pengiriman bahan dapat dihilangkan atau dikurangi

- Menyesuaikan dengan jadwal produksi

- Menjaga Komitmen terhadap permintaan pelanggan

- Dapat menambah keuntungan dengan memanfaatkan diskon jumlah pembelian

- Memberikan waktu yang tepat untuk pengelolaan produksi dan pembelian (lead time)

\subsection{Healthy Inventory}

Hampir semua bisnis yang sukses tergantung dengan manajemen persediaan yang dikelola dengan baik. Jika bisnis tersebut memiliki kesalahan dalam mengelola persediaan atau tidak memiliki persediaan yang cukup, akan sulit dikatakan jika manajemen persediaannya berada di area healthy inventory. Untuk mendefinisikan "healthy inventory" ini akan sangat berbeda karena bergantung pada persyaratan atau kebutuhan individu dan tujuan bisnis. Secara umum healthy inventory terutama memiliki persediaan yang cukup untuk melayani permintaan (bisnis) sambil secara bersamaan untuk tetap bisa menjaga tingkat persediaan kadaluarsa dan berlebihan agar tetap rendah. Namun, memiliki proses yang baik untuk pengambilan sebuah keputusan, mengekstrak nilai maksimum dari data persediaan dan mengoperasikan fungsi dari manajemen persediaan yang efisien juga merupakan metric yang relevan mengenai fungsi healthy inventory manajemen. Healthy inventory berarti berhasil menyeimbangkan antara biaya persediaan dan permintaan pelanggan. Setelah menentukan tingkat persediaan yang ideal untuk sebuah perusahaan/bisnis, berikut adalah beberapa cara untuk membantu agar menjaga tingkat persediaan tetap berada pada level healthy inventory.

- Membuat inventory team; jika saat ini keputusan pembelian sebuah material hanya diputuskan oleh satu orang, maka sebagai gantinya dapat dibuat tim yang berdedikasi untuk membuat keputusan pembelian tersebut. Tim inventory ini dapat dibentuk dari beberapa orang yang memiliki berbagai peran misalnya: bagian pemasaran dapat dilibatkan karena mengetahui permintaan yang akan datang, bagian pembelian, perencanaan produksi, dan logistik, sehingga sesekali (weekly, monthly, quarterly) dapat meninjau persediaan yang sudah usang (obsolete)

- Menahan sebelum memesan; memutuskan jumlah pemesanan yang dibutuhkan tidak menjadi seperti permainan tebak-tebakan. Memesan terlalu banyak berarti persediaan berlebih akan dibiarkan berada digudang yang membutuhkan ruang penyimpanan, biaya penyimpanan meningkat, hingga menimbulkan biaya provisi material tersebut. Pemesanan yang tidak cukup bisa berarti kehabisan persediaan saat permintaan sedang tinggi. Luangkan waktu untuk memeriksa bulan-bulan sebelumnya apakah terdapat perubahan yang perlu dilakukan terhadap pemesanan rutin untuk menghindari masalah. 
- Membuat tindakan untuk menurunkan nilai provisi persediaan; kelebihan persediaan akan menyebabkan beberapa masalah bagi perusahaan. Idealnya, kelebihan material tersebut dapat dijual kembali ke pemasok (vendor/principal), atau memberikan intensif kepada tim pemasaran/penjualan untuk menjual ekstra kepada pelanggan. Namun jika tidak memungkinkan, kelebihan persediaan bisa dieliminasi dengan menawarkan buy one-get one, free discount dan sejenisnya.

- Implementasi sistem kontrol persediaan; setelah kita melakukan pembelian terhadap suatu barang, sistim kontrol inventory dapat membantu menghitung dan mengelolanya dengan akurat. Dengan bantuan sistim kontrol inventory ini bisa didapatkan pula visibilitas dan kontrol tingkat inventory, mengurangi waktu yang dihabiskan untuk mencari persediaan. Menerapkan sistim kontrol inventory seperti ini akan membantu dalam mempertahankan healthy inventory, dan pada akhirnya membantu bisnis berjalan lebih lancar dan efisien.

Tingkat persediaan yang optimal adalah jumlah produk ideal yang harus dimiliki di pusat pemenuhan pada waktu tertentu. Dengan mengoptimalkan tingkat persediaan, maka kita dapat mengurangi risiko masalah umum persediaan mulai dari biaya penyimpanan yang tinggi hingga kehabisan persediaan.

\subsection{Nilai Provisi Material}

Yang dimaksud dengan biaya provisi adalah biaya perkiraan yang berhubungan dengan persediaan karena adanya kesalahan dan harus ditanggung oleh perusahaan. Pada dasarnya, biaya provisi yang terjadi merupakan kerugian langsung dan akan mengurangi keuntungan yang dihasilkan sehingga tidak akan ada satupun perusahaan yang pada akhirnya menginginkan membayar biaya provisi ini. Ada dua kejadian yang ada didalam biaya provisi, yaitu;

- Biaya provisi untuk barang-barang yang kadaluarsa, dan

- Biaya provisi untuk barang-barang yang berlebih jika dibandingkan dengan waktu bayar perusahaan (term of payment).

Sebagai contoh: ada sebuah perusahaan yang berencana akan menjual produk A sebanyak 800 unit pada bulan depan, agar dapat memenuhi dan mencapai target penjualan yang telah ditetapkan tersebut, maka dari bagian pembelian diminta untuk segera membeli dan menyediakan barang sebagai persediaan sebanyak 1,000 unit. Permasalahan tidak akan timbul ketika aktual penjualan pada bulan mendatang yang terjadi memang mendekati 800 unit atau mungkin aktual penjualannya bisa kurang ataupun lebih sedikit dari 800 unit. Masalah baru akan dimulai ketika suatu kondisi yang terjadi dimana aktual penjualan pada tiga bulan secara berturut-turut dari produk A tersebut ternyata hanya terjual 30 unit, 50 unit dan 70 unit. Maka, dapat kita ketahui bahwa penjualan produx A dalam 3 bulan tersebut yang hanya terjual ratarata 50 unit perbulan, sehingga untuk sisa persediaan yang ada saat ini menjadi 850 unit/50 unit atau dapat dikatakan sisa persediaan dapat memenuhi kebutuhan hingga 17 bulan kedepan. Dengan kata lain, persediaan yang ada di perusahaan tersebut akan akan disimpan untuk waktu penyimpanan hampir 1,5 tahun kedepan. Tentu saja terdapat potensi kerugian yang akan terjadi jika persediaan barang tersebut yang mungkin pada akhirnya tidak terjual atau mungkin saja terjual tetapi dalam waktu yang cukup lama. Potensi seperti inilah yang akan diperkirakan dan dihitung dan menjadi sebuah nilai provisi (biaya provisi) yang harus di tanggung oleh perusahaan.

Dalam menentukan seberapa besar biaya provisi yang harus ditanggung oleh perusahaan dapat ditentukan oleh kesepakatan manajemen, khususnya di bagian keuangan, dan tentunya juga akan tergantung dengan jenis produk apa yang dibuat. Kita ambil contoh yang ada didalam 
kasus ini ditetapkan bahwa biaya provisi untuk over stock 0-3 bulan adalah 0\%, 3-6 bulan adalah sebesar 25\%, antara 6-12 bulan adalah sebesar 50\% dan $100 \%$ jika diatas 1 tahun. Dengan demikian cara untuk menghitung biaya provisinya adalah sebagai berikut; misalkan jumlah stock barang A ada 100pcs, permintaan dalam 3 bulan kedepan adalah 35pcs, selanjutnya dalam 3-6 bulan berikutnya adalah 25pcs, dan dalam 6-12 bulan berikutnya adalah 16pcs, masa kadaluarsa barang A tersebut adalah 18 bulan. Maka perhitungan potensial kerugian perusahaan terhadap barang-barang yang akan kadaluarsa menjelang 18 bulan kedepan harus ditetapkan. Ilustrasi perhitungan nilai provisi dapat dilihat dalam tabel 1. Ilustrasi perhitungan nilai provisi material berikut:

Tabel 1. Ilustrasi perhitungan nilai provisi material

\begin{tabular}{|c|c|c|c|c|c|}
\hline Material & $\begin{array}{c}\text { Jumlah } \\
\text { Stock }\end{array}$ & $\begin{array}{c}\text { Permintaan } \\
\text { 0-3 Bulan }\end{array}$ & $\begin{array}{c}\text { Permintaan } \\
\text { 3-6 Bulan }\end{array}$ & $\begin{array}{c}\text { Permintaan } \\
\text { 6-12 Bulan }\end{array}$ & $\begin{array}{c}\text { Permintaan } \\
>12 \text { Bulan }\end{array}$ \\
\hline $\mathrm{A}$ & 100 & 35 & 25 & 16 & 0 \\
\hline & Sisa Stock & 65 & 40 & 24 & 24 \\
\hline $\begin{array}{c}\text { Nilai } \\
\text { Provision }\end{array}$ & $0 \%$ & $25 \%$ & $50 \%$ & $100 \%$ \\
\hline
\end{tabular}

Dari ilustrasi diatas kita bisa menghitung dan mengetahui nilai provisi material A yaitu 10pcs, 12pcs dan 24pcs sehingga total nilai provisinya sejumlah 46pcs. Dari semua barang A yang berpotensi akan kadaluarsa dalam waktu 18 bulan kedepan ini harus dihitung sebagai biaya yang harus dianggarkan dan tentu saja ini akan menjadi potensial kerugian yang harus ditanggung oleh perusahaan karena berpotensi barang tersebut akan menjadi scrap.

Ada beberapa strategi yang dapat dilakukan perusahaan untuk dapat meminimalisasi terjadinya nilai provisi/biaya provisi ini, antara lain adalah sebagai berikut;

- Melakukan konsinyasi (consignment) dalam pembelian barang; dapat dikatakan ini adalah salah satu cara termudah yang akan menjamin perusahaan bebas dari biaya provisi. Akan tetapi, yang menjadi tantangan besarnya adalah bagaimana perusahaan pada akhirnya dapat mencari pemasok dengan fasilitas konsinyasi (consignment) tersebut.

Konsinyasi adalah suatu perjanjian dimana pembayaran barang kepada pemasok hanya dilakukan berdasarkan jumlah barang yang sudah terjual.

- Adanya perjanjian kerjasama untuk pengembalian barang ke pemasok; jika pembelian barang dengan cara konsinyasi tidak dapat dicapai, perusahaan dapat mencari cara bagaimana dapat melakukan pengembalian barang (return) ke pemasok. Sehingga risiko untuk barang-barang yang berpotensi akan kadaluarsa, rusak atau kelebihan barang dapat dihindari. Sehingga pada akhirnya perusahaan dapat menghilangkan biaya provisi dengan ccara melakukan pengembalian risiko tersebut ke pemasok. Namun kendalanya adalah tidak semua pemasok bersedia untuk melakukan perjanjian pengembalian barang dengan semua alasan yang ada seperti diatas.

- Tingkat akurasi peramalan penjualan yang lebih baik; dua cara yang sudah disebutkan sebelumnya masih terdapat ketergantungan dari pihak luar, untuk mengantisipasi biaya provisi dari dalam perusahaan sendiri dapat dilakukan dengan cara memperbaiki dan menjaga tingkat akurasi (forecast) penjualan. Dapat dipastikan risiko biaya provisi akan menjadi minimal ketika tingkat akurasi penjualan sangat baik. 
- Melakukan strategi penjualan barang dengan kondisi khusus; masih ada cara yang lain yang memungkinkan perusahaan dapat terbebas dari biaya provisi, yaitu dengan cara melakukan penjualan dengan kondisi promosi seperti pemberian diskon atau perpanjangan waktu pembayaran kepada konsumen. Namun dengan cara ini tidak $100 \%$ menjamin perusahaan akan terbebas dari biaya provisi, tetapi paling tidak dengan menerapkan cara seperti ini perusahaan dapat mengurangi biaya provisi yang mungkin seharusnya bisa timbul lebih besar lagi.

\section{KESIMPULAN}

Karena pergerakan barang saat berlangsungnya proses produksi, maka dapat dikatakan bahwa proses produksi merupakan proses yang dinamis. Untuk itu agar tidak mengganggu keberlangsungan proses produksi, diperlukan pengelolaan yang baik terhadap barang tersebut. Manajemen persediaan memainkan peranan penting dalam menyeimbangkan manfaat dan kerugian yang terkait dengan penyimpanan dan pengelolaan persediaan. Untuk itu diperlukan kebijakan pengendalian untuk menentukan level persediaan yang harus dijaga, kapan waktunya untuk menambah persediaan harus dilakukan dan seberapa besar pesanan yang harus disiapkan. Dengan melakukan sistem kontrol persediaan ini akan menentukan dan menjamin tersedianya persediaan yang tepat dalam kuantitas dan waktu yang tepat. Tingkat persediaan yang optimal adalah ketika jumlah persediaan yang kita miliki dapat memenuhi semua permintaan pada waktu tertentu. Dengan mengoptimalkan tingkat persediaan, maka kita dapat mengurangi risiko masalah umum persediaan, mulai dari biaya penyimpanan yang tinggi hingga biaya kehabisan stock.

Dalam aktivitas persediaan barang (inventory) terdapat potensi biaya provisi yang merupakan perhitungan risiko yang akan ditanggung oleh perusahaan. Dengan sistem kontrol persediaan yang baik, maka beban biaya nilai provisi ini dapat di tekan seminimal mungkin sehingga tidak mengganggu profit perusahaan. Dengan demikian maka keuntungan perusahaan yang akan dicapai dapat di maksimalkan.

Untuk selanjutnya bagaimana menentukan formula perhitungan yang sesuai ketika perusahaan dapat menentukan dan mengukur bahwa tingkat persediaannya sudah masuk dalam kategori healthy inventory atau tidak?

\section{DAFTAR PUSTAKA}

Chapman, S. N., Arnold, J. R. Tony, Gatewood, A. K. Clive, L. M. 2017. Introduction to Materials Management, 8 $^{\text {th }}$ Edition. Pearson Education Inc.

Grob, Christopher. 2018. Inventory Management in Multi-Echelon Networks On the Optimization of Reorder Points. AutoUni-Schriftenreihe Springer.

Karim, N.A., Nawawi, Anuar, Salin, Ahmad S.A.P. 2017. Inventory Management effectiveness of a manufacturing company - Malaysian Evidence. International Journal of Law and Management Vol. 60 No.5.

Logistik Indonesia, Jurus Pengaman Inventory: Provisi, 6 Agustus 2010, 19 April 2017 $<$ http://logistikindonesia.blogspot.com/>

Nur, Rusdi. Suyuti, Muhammad Arsyad. 2017. Pengantar Sistem Manufaktur, Deepublish.

Pujawan, I Nyoman. Er, Mahendrawathi. 2017. Supply Chain Management Edisi 3. Penerbit Andy Yogyakarta.

Shenoy, Dinesh. Rosas, Roberto. 2018. Problems \& Solutions in Inventory Management. Springer.

Silver, Edward A., Pyke, David F., Thomas, Douglas J. 2017. Inventory and Production Management in Supply Chains, Fourth Edition. CRC Press.

Siswandi. 2010. Manajemen Keuangan. Lentera Ilmu Cendikia 